\title{
KEPUTIHAN PADA WANITA USIA SUBUR MENGGUNAKAN EKSTRAK DAUN SIRSAK
}

\author{
Suwanti, Yonferizal MR Koto \\ Kementerian Kesehatan Politeknik Kesehatan Surakarta Jurusan Kebidanan
}

\begin{abstract}
The leaves of the soursop, woman of fertile age, Whitish. Whitish is the complaint most often found in women. Cause of vaginal discharge is a matter of cleanliness around the sex organs, such as less clean when dry the sex organs after urination and defecation. Soursop leaf oil contains asitrin, sineol 50\% -65\%, apinene, limonene and dipenten, mngandung asetogini compounds, among others asimisin, bulatasin and skuamosin. Peneitian goal is to determine the effectiveness of the use of soursop leaves against vaginal discharge in women of childbearing age. The research design was quasi experiment with pretest posttes approach, where the study was conducted grouping members of the experimental group. The subjects of this study were women of childbearing age who experience vaginal discharge by 30 samples. The statistical test used in this study is the Mann Whitney U Test. The results showed that women of childbearing age who experience vaginal discharge cured after taking the leaf extract of soursop 23 people (76.7\%).
\end{abstract}

Keywords: Soursop Leaves, Woman Of Fertile Age, Whitish

Abstrak: Daun sirsak, Wanita Usia Subur, Keputihan. Keputihan merupakan keluhan yang paling sering ditemukan pada wanita. Penyebab keputihan adalah masalah kebersihan di sekitar organ intim, seperti kurang bersih saat mengeringkan bagian organ intim setelah buang air kecil dan buang air besar. Daun sirsak mengandung minyak asitrin, sineol 50\%-65\%, a-pinen, limonene dan dipenten, mngandung senyawa asetogini, antara lain asimisin, bulatasin dan skuamosin. Tujuan peneitian ini adalah untuk mengetahui efektifitas penggunaan daun sirsak terhadap keputihan pada wanita usia subur. Desain penelitian ini adalah quasi eksperiment dengan pendekatan pretest posttes, dimana penelitian ini dilakukan pengelompokan anggota kelompok eksperimen. Subyek penelitian ini adalah wanita usia subur yang mengalami keputihan sebesar 30 sampel. Uji statistik yang digunakan pada penelitian ini adalah Mann Whitney U Test. Hasil penelitian menunjukkan bahwa wanita usia subur yang mengalami keputihan sembuh setelah mengkonsumsi ekstrak daun sirsak 23 orang $(76,7 \%)$.

Kata Kunci: Daun sirsak, Wanita Usia Subur, Keputihan

\section{PENDAHULUAN}

Masalah keputihan adalah masalah yang sejak lama menjadi persoalan bagi kaum wanita. Keputihan adalah keluarnya sekret atau cairan dari vagina. Sekret tersebut dapat bervariasi dalam konsistensi, warna dan bau. Keputihan dapat diartikan sebagai semacam lendir yang keluar terlalu banyak, warnanya putih seperti sagu kental dan agak kekuning-kuningan, jika slim atau lendir ini tidak terlalu banyak, tidak menjadi persoalan. Umumnya wanita yang menderita keputihan mengeluarkan lendir tersebut terlalu banyak dan menimbulkan bau yang tidak enak. Ini disebabkan karena terjadinya peradangan dan infeksi pada liang vagina. Jika keputihan sudah berlarutlarut dan menjadi berat, maka kemungkinan wanita yang bersangkutan 
akan menjadi mandul (Octaviyanti, 2008).

Diperkirakan sebanyak $75 \%$ wanita di Indonesia pernah mengalami keputihan minimal satu kali dalam hidupnya (Putranto, 2006). Di dalam vagina terdapat lingkaran kehidupan yang disebut dengan ekosistem vagina. Lingkaran kehidupan ini sangat di pengaruhi oleh estrogen dan laktobasilus (bakteri baik). Pada saat kondisi normal, semuanya seimbang dan tidak terjadi gangguan. Bila terjadi ketidak seimbangan akibat adanya perubahan suhu atau kadar kelembaban maka akan menyebabkan bakteri pathogen (bakteri buruk). Kondisi ini akan menyebabkan tubuh rentan terhadap infeksi (Kinanti, 2009).

Wanita Usia Subur (WUS) Berdasarkan Konsep Departemen Kesehatan (2003) adalah wanita dalam usia reproduktif, yaitu usia 15 - 49 tahun baik yang berstatus kawin, janda maupun yang belum nikah. Jumlah wanita di dunia yang pernah mengalami keputihan sekitar 75\% (Zubier, 2002), sedangkan wanita Eropa yang mengalami keputihan sebesar $25 \%$, dan untuk wanita Indonesia yang mengalami keputihan berjumlah 75\% (Octaviyanti, 2006).

World Health Organization (WHO) telah menyarankan negaranegara membangun untuk memanfaatkan penggunaan pengobatan tradisional dalam bidang kesehatan (Adeltrudes B \& Marina O., 2010). Selain itu pemerintah Indonesia juga mendukung tanaman obat tradisional sebagai alternatif pengobatan karena negara Indonesia merupakan negara yang kaya akan tumbuhan tradisional (Rianti D \& Yogyarti S., 2006). Berdasarkan Keputusan Menteri Kesehatan Republik Indonesia Nomor 1076/ MENKES/ SK/ VII/ 2003 tentang penyelenggaraan pengobatan tradisional, menerangkan bahwa pengobatan tradisional yang dapat dipertanggung jawabkan manfaat dan keamanannya perlu terus dibina, ditingkatkan, dikembangkan, dan diawasi untuk digunakan dalam mewujudkan derajat kesehatan yang optimal. Salah satu tumbuhan tradisional tersebut adalah daun sirih.

Daun sirsak mengandung minyak asitrin, sineol 50\%-65\%, a-pinen, limonene dan dipenten, mengandung senyawa asetogini, antara lain asimisin, bulatasin dan skuamosin. Pada kosentrasi tinggi, senyawa asetogenin memiliki keistimewaan sebagai antifeedent, disamping itu juga mengandung zat annonaceous acetogenins yang mampu 10.000 kali lebih kuat membunuh sel-sel kanker dari pada zat adriamycin, yang biasa pakai dalam pengobatan kemotrapi. Zat acetogenins dapat membunuh aneka jenis kanker, seperti kanker usus, tiroid, pospat, paru-paru, payudara, dan pankreas bahkan penyakit ambien tanpa merusak atau menganggu sel-sel tubuh yang sehat (Kementrian Kesehatan, 2011). Keputihan dapat dicegah melalui gaya hidup yang sehat seperti membersihkan vagina setelah buang air dengan gerakan dari depan ke belakang, mengeringkan vagina dengan tisu sekali usap, dan tidak duduk di toilet karena keputihan dapat menular melalui bibir kloset, dan perlengkapan mandi seperti handuk (Junita, 2006). Untuk mencegah terjadinya keputihan pada seorang wanita diperlukan pengetahuan tentang keputihan, karena keputihan yang tidak diobati terutama keputihan patologis dapat menyebabkan infeksi indung telur, yang dapat mengakibatkan kemandulan (Candraningrum, 2003).

Keputihan dapat dicegah melalui gaya hidup yang sehat seperti membersihkan vagina setelah buang air dengan gerakan dari depan ke belakang, mengeringkan vagina dengan tisu sekali usap, dan tidak duduk di toilet karena keputihan dapat menular melalui bibir kloset, dan perlengkapan mandi seperti 
handuk (Junita, 2006). Untuk mencegah terjadinya keputihan pada seorang wanita diperlukan pengetahuan tentang keputihan, karena keputihan yang tidak diobati terutama keputihan patologis dapat menyebabkan infeksi indung telur, yang dapat mengakibatkan kemandulan (Candraningrum, 2003).

Berdasarkan latar belakang tersebut dapat dirumuskan masalah "Bagaimanakah Efektifitas Penggunaan Daun Sirsak Terhadap Keputihan Pada Wanita Usia Subur di wilayah Bidan Praktek Mandiri Klaten “.

\section{METODE PENELITIAN}

Desain penelitian quasi eksperiment dengan rancangan pretest posttes, yaitu dalam rancangan ini dilakukan pengelompokan anggota kelompok eksperimen yang dilaksanakan pada bulan Januari sampai Juni 2015. Populasi wanita usia subur yang mengalami keputihan yang berada di wilayah bidan praktek mandiri Klaten, dengan sampel 30 orang yang diambil secara Accidental Sampling. Instrumen yang digunakan lembar observasi dan menggunakan uji statistic Mann Whitney U Test

\section{HASIL PENELITIAN}

Dari hasil penelitian di Bidan Praktek Mandiri Kabupaten Klaten didapatkan data wanita usia subur yang mengalami keputihan yang telah mengkonsumsi ekstrak daun sirsak diperoleh data sebagai berikut:

\section{Tabel 1}

Distribusi Frekuensi Umur WUS di Bidan Praktek Mandiri Kabupaten

\section{Klaten}

\begin{tabular}{clcc}
\hline No & \multicolumn{1}{c}{ Umur } & Frekuensi & $\%$ \\
\hline 1 & $<20$ tahun & 0 & 0 \\
2 & $20-35$ tahun & 21 & 70 \\
3 & $>35$ & 9 & 30 \\
\hline & Jumlah & 30 & 100 \\
\hline \multicolumn{2}{r}{ Tabel } & $\mathbf{2}$
\end{tabular}

Tabel 2

Distribusi Frekuensi Pendidikan WUS di Bidan Praktek Mandiri Kabupaten Klaten

\begin{tabular}{|c|c|c|c|c|}
\hline No & Pendidikan & Frekuensi & \multicolumn{2}{|c|}{$\%$} \\
\hline 1 & $\mathrm{SD}$ & 4 & \multicolumn{2}{|c|}{13,3} \\
\hline 2 & SMP & 5 & \multicolumn{2}{|c|}{16,7} \\
\hline 3 & SMA & 16 & \multicolumn{2}{|c|}{53,3} \\
\hline 4 & PT & 5 & \multicolumn{2}{|c|}{16,7} \\
\hline & Jumlah & 30 & \multicolumn{2}{|c|}{100} \\
\hline No & \multicolumn{2}{|c|}{$\begin{array}{c}\text { Kejadian } \\
\text { Keputihan } \\
\end{array}$} & Frek & $(\%)$ \\
\hline 1 & \multicolumn{2}{|c|}{ Sembuh } & 23 & 76,7 \\
\hline 2 & \multicolumn{2}{|c|}{ Tidak Sembuh } & & 23,3 \\
\hline & \multicolumn{2}{|c|}{$\begin{array}{l}\text { a. Berubah warna } \\
\text { (kuning, abu abu, } \\
\text { putih susu) }\end{array}$} & 1 & 3,3 \\
\hline & \multirow{2}{*}{\multicolumn{2}{|c|}{$\begin{array}{l}\text { b. Berbau (amis, } \\
\text { anyir) }\end{array}$}} & 2 & 6.7 \\
\hline & & & 1 & 3,3 \\
\hline & \multicolumn{2}{|c|}{$\begin{array}{l}\text { c. Berasa gatal, panas } \\
\text { d. Cairan yang }\end{array}$} & 2 & 6,7 \\
\hline & \multicolumn{2}{|c|}{$\begin{array}{l}\text { keluar terus } \\
\text { menerus }\end{array}$} & 1 & 3,3 \\
\hline & \multicolumn{2}{|c|}{$\begin{array}{l}\text { e. Sifat cairan : } \\
\text { encer, menggumpal }\end{array}$} & & \\
\hline & \multicolumn{2}{|l|}{ Jumlah } & 30 & 100 \\
\hline
\end{tabular}

Tabel 3

Distribusi Frekuensi Pekerjaan WUS di Bidan Praktek Mandiri Kabupaten Klaten

\begin{tabular}{clcc}
\hline No & Pekerjaan & Frekuensi & $\%$ \\
\hline 1 & Bekerja & 14 & 46,7 \\
2 & Tidak & 16 & 53,3 \\
& Bekerja & & \\
\hline & Jumlah & 30 & 100 \\
\hline
\end{tabular}

Tabel 4

Distribusi Frekuensi Paritas WUS di Bidan Praktek Mandiri Kabupaten

Klaten

\begin{tabular}{clcc}
\hline No & \multicolumn{1}{c}{ Paritas } & Frekuensi & $\%$ \\
\hline 1 & Primipara & 5 & 16,7 \\
2 & Multipara & 24 & 80 \\
3 & Grandemultipara & 1 & 3,3 \\
\hline & Jumlah & 30 & 100 \\
\hline
\end{tabular}

Tabel 5

Distribusi Frekuensi Kejadian Keputihan Setelah penggunaan di Bidan Praktek Mandiri Kabupaten Klaten

\begin{tabular}{clcc}
\hline No & \multicolumn{1}{c}{$\begin{array}{c}\text { Kejadian } \\
\text { Keputihan }\end{array}$} & Frekuensi & $(\%)$ \\
\hline 1 & Sembuh & 23 & 76,7 \\
2 & Tidak Sembuh & 7 & 23,3 \\
\hline \multicolumn{4}{c}{ Tumlah Tabel 6 } \\
\multicolumn{4}{c}{ Distribusi Frekuensi Lama } \\
Penyembuhan Keputihan di Bidan \\
Praktek Mandiri Kabupaten Klaten
\end{tabular}




\begin{tabular}{clcc}
\hline No & Lama & Frekuensi & $(\%)$ \\
\hline 1 & Hari ke 1 & 0 & 0 \\
2 & Hari ke 2 & 0 & 0 \\
3 & Hari ke 3 & 0 & 0 \\
4 & Hari ke 4 & 0 & 0 \\
5 & Hari ke 5 & 1 & 3,3 \\
6 & Hari ke 6 & 6 & 20 \\
7 & Hari ke 7 & 0 & 0 \\
8 & Hari ke 8 & 5 & 16,7 \\
9 & Hari ke 9 & 0 & 0 \\
10 & Hari ke 10 & 5 & 16,7 \\
11 & Hari ke 11 & 0 & 0 \\
12 & Hari ke 12 & 5 & 16,7 \\
13 & Hari ke 13 & 0 & 0 \\
14 & Hari ke 14 & 1 & 3,3 \\
15 & Tidak & 7 & 23,3 \\
& sembuh & & \\
\hline \multicolumn{7}{c}{ Jumlah } & 30 & 100 \\
\hline
\end{tabular}

\section{Tabel 7}

Distribusi Frekuensi Tanda dan Gejala Kejadian Keputihan di Bidan Praktek Mandiri Kabupaten Klaten

Berdasarkan tabel 7 dapat diketahui bahwa responden yang belum sembuh sebanyak 7 orang $(23,3 \%)$ dengan gejala atau keluhan yang masih ada yaitu berubah warna menjadi kuning, abu-abu dan putih susu sebanyak 1 orang $(3,3 \%)$, sebanyak 2 orang $(6,7 \%)$ dengan gejala berbau amis atau anyir,terdapat 1 orang $(3,3 \%)$ dengan gejala berasa gatal dan panas, terdapat 2 orang $(6,7 \%)$ dengan gejala cairan yang keluar terus menerus dan 1 orang $(3,3 \%)$ dengan gejala sifat cairan encer dan menggumpal.

Analisa bivariat adalah untuk mengetahui hubungan dua variabel yaitu efektifitas penggunaan daun sirsak terhadap kejadian keputihan pada wanita usia subur.

\section{Tabel 8}

Eefektifitas penggunaan daun sirsak terhadap kejadian keputihan

\begin{tabular}{|c|c|c|c|c|c|c|}
\hline \multirow{3}{*}{$\begin{array}{c}\text { Penggu } \\
\text { naan } \\
\text { Sirsak }\end{array}$} & \multicolumn{4}{|c|}{$\begin{array}{c}\text { Kejadian } \\
\text { Keputihan } \\
\end{array}$} & \multirow{3}{*}{$\mathrm{p}$} & \multirow{3}{*}{$\mathrm{Z}$} \\
\hline & \multicolumn{2}{|c|}{ Sembuh } & \multicolumn{2}{|c|}{ Tidak } & & \\
\hline & $\mathrm{f}$ & $\%$ & $\mathrm{f}$ & $\%$ & & \\
\hline Sebelu & 30 & 100 & 23 & 76 & 0,00 & 4,7 \\
\hline $\begin{array}{l}\mathrm{m} \\
\text { Sesuda } \\
\mathrm{h}\end{array}$ & 0 & 0 & 7 & 23 & & 96 \\
\hline Jumlah & 30 & 100 & 30 & 100 & & \\
\hline
\end{tabular}

\section{PEMBAHASAN}

Berdasarkan hasil penelitian umur wanita usia subur adalah 20-35 tahun dan lebih dari 35 tahun sebanyak 9 orang (30\%). Sedangkan dilihat dari umur wanita usia subur yang menjadi responden paling muda adalah 20 tahun dan paling tua adalah 49 tahun. Hasil ini menunjukkan umur wanita usia subur adalah 20-49 tahun. Wanita usia subur (WUS) adalah wanita yang sudah mengalami menstruasi dengan umur sampai 15- 49 tahun (Hanafi, 2004). Wanita Usia Subur (WUS) berdasarkan konsep Departemen kesehatan (2003) adalah wanita dalam usia reproduktif, yaitu usia 15 - 49 tahun baik yang berstatus kawin, janda maupun yang belum nikah.

Data menurut pekerjaan wanita usia subur sebagian besar adalah tidak bekerja sebanyak 16 orang $(53,3 \%)$. Keputihan tidak bisa dipungkiri salah satunya oleh kondisi fisik wanita yang terkuras energi maupun psikisnya sebab mengerjakan pekerjaan berat atau aktivitas ekstra lainnya. Penyebab keputihan dari keletihan ditandai muncul hanya pada waktu kondisi tubuh sangat capek dan biasa lagi ketika tubuh sudah normal kembali (Susanto, 2013).

Sedangkan pendidikan responden sebagian besar adalah SMA sebanyak 16 orang $(53,3 \%)$. Pendidikan wanita usia subur dapat meningkatkan pemahaman terhadap suatu hal, dalam hal ini pengobatan atau pencegahan keputihan. Untuk mencegah terjadinya keputihan pada seorang wanita diperlukan pengetahuan tentang keputihan, karena keputihan yang tidak diobati terutama keputihan patologis dapat menyebabkan infeksi indung telur, yang dapat mengakibatkan kemandulan (Candraningrum, 2003).

Paritas responden sebagian besar multipara, keadaan ini menunjukkan bahwa sebagian wanita usia subur yang keputihan sudah melahirkan lebih dari anak satu. Keputihan dapat dicegah 
melalui gaya hidup yang sehat seperti membersihkan vagina setelah buang air dengan gerakan dari depan ke belakang, mengeringkan vagina dengan tisu sekali usap, dan tidak duduk di toilet karena keputihan dapat menular melalui bibir kloset, dan perlengkapan mandi seperti handuk (Junita, 2006).

Sirsak (Annona merucita linn) atau Sirsat yang tanaman ini yang berasal dari Karibia, Amerika Tengah dan Amerika Selatan. Nama asli dari buah ini adalah Zuurzak yang diambil dari bahasa belanda yang berarti "Kantong Asam" buah ini masuk di Indonesia pada masa penjajahan Belanda di Abad Ke 19 dan orang Indonesia susah menyebutnya nama buah tersebut. Untuk mempermudah, orang Indonesia menyebutnya sirsak. Di Inggris buah sirsak bernama soursop (Mahfud Suseno, 2013).

Hasil penelitian menunjukkan bahwa sebelum mengkonsumsi sirsak semua responden keputihan, setelah mengkonsumsi sirsak sebanyak 23 orang (76,7\%) sembuh dari keputihan dengan waktu paling cepat hari ke 5 dam paling lama hari ke 14. Hal ini menunjukkan bahwa daun sirsak mempengaruhi lama penyembuhan kejadian keputihan. Didukung dengan daun sirsak mengandung Minyak asitrin, sineol 50\%-65\%, a-pinen, limonene dan dipenten, mngandung senyawa asetogini, antara lain asimisin, bulatasin dan skuamosin, Pada kosentrasi tinggi, senyawa asetogenin memiliki keistimewaan sebagai antifeedent, disamping itu juga mengandung zat annonaceous acetogenins yang mampu 10.000 kali lebih kuat membunuh sel-sel kanker dari pada zat adriamycin, yang biasa pakai dalam pengobatan kemotrapi. Zat acetogenins dapat membunuh aneka jenis kanker, seperti kanker usus, tiroid, pospat, paru-paru, payudara, dan pankreas bahkan penyakit ambien tanpa merusak atau menganggu sel-sel tubuh yang sehat (Kementrian Kesehatan, 2011).

Hasil penelitian menunjukkan bahwa 7 orang responden tidak sembuh setelah menggunakan daun sirsak, namun masih ada gejala keputihan seperti berubah warna menjadi kuning, abu-abu dan putih susu sebanyak 1 orang $(3,3 \%)$, sebanyak 2 orang $(6,7 \%)$ dengan gejala berbau amis atau anyir,terdapat 1 orang $(3,3 \%)$ dengan gejala berasa gatal dan panas, terdapat 2 orang $(6,7 \%)$ dengan gejala cairan yang keluar terus menerus dan 1 orang $(3,3 \% 0$ dengan gejala sifat cairan encer dan menggumpal. Keadaan ini dikarenakan ibu bekerja sehingga kondisi fisik wanita yang terkuras energi maupun psikisnya sebab mengerjakan pekerjaan berat atau aktivitas ekstra lainnya, yang mengakibatkan keletihan dan gejala keputihan tetap muncul.

Berdasarkan hasil analisis dapat diketahui bahwa ada penggunaan daun sirsak efektif terhadap kejadian keputihan dengan nilai $\mathrm{Z}=4,796$ dan nilai $\mathrm{p}=0,000 \quad(\mathrm{p}<0,05)$. Maytasari, GM(2010), dengan judul "Perbedaan Efek Antifungi Minyak Atsiri Daun Sirih Hijau, Minyak Atsiri Daun Sirih Merah Dan Resik- V Sabun Sirih Terhadap Pertumbuhan Candida Albicans. Hasil ini dibuktikan dengan setelah menggunakan daun sirsak maka lama penyembuhan keputihan rata-rata 6 hari dan paling sedikit hari ke 5 sudah sembuh.

Daun sirsak dapat untuk mengobati keputihan pada wanita karena mengandung zat antiseptik yang dapat membunuh kuman, yaitu fenol, dimana kandungan fenol dalam daun sisak memiliki sifat antiseptik 5 kali lebih efektif dibandingkan fenol biasa. Untuk mengobati keputihan rebus 10 daun sirsak dalam 2,5 liter air, kemudian rebusan yang masih hangat tersebut untuk mencuci vagina (Triarsari, 2007).

Pengobatan keputihan tergantung dari penyebab infeksi jamur, bakteri, 
atau parasit. Umumnya diberikan obatobatan untuk mengatasi keluhan dan menghentikan proses infeksi sesuai dengan penyebabnya. Obat- obatan yang digunakan dalam mengatasi keputihan biasanya berasal dari golongan flukonazol untuk mengatasi infeksi candida dan golongan metronidazol untuk mengatasi infeksi bakteri dan parasit. Flukonazol untuk pemakaian per oral dalam kapsul yang mengandung 50, 100, 150, $200 \mathrm{mg}$. Dosis yang disarankan 100-400 mg per hari.

\section{KESIMPULAN SARAN}

Berdasarkan hasil penelitian, pembahasan, tinjauan teori dan penelitian pendukung serta factor-faktor yang mempengaruhi kejadian keputihan maka dapat disimpulkan bahwa ekstrak daun sirsak efektif terhadap kejadian keputihan.

Berdasarkan kesimpulan tersebut dapat diberikan saran sebagai berikut :

1. Bagi Wanita Usia Subur

Diharapkan dapat menggunakan daun sirsak untuk mengurangi gejala keputihan dengan cara penggunaan yang benar dan rutin dan sebagai , wacana dan tambahan pengetahuan tentang penggunaan daun sirih untuk mengatasi keputihan.

2. Bagi Bidan praktek di BPM Klaten Diharapkan dapat membantu mempopulerkan penggunaan edno medisin tradicional daun sirsak baik dalam bentuk ekstrak ataupun daun sirsak sebagai alternatif dalam mengobati / mengatasi gejala keputihan kepada masyarakat khususnya wanita usia subur.

3. Bagi Tenaga Kesehatan

Informasi tentang pemakaian ekstrak daun sirsak harus tetap disosialisasikan lebih luas dan lebih optimal dan tenaga kesehatan hendaknya meningkatkan dalam memberikan penyuluhan kepada masyarakat khususnya WUS yang keputihan bahwa penggunaan ekstrak daun sirsak dapat mencegah/mengobati keputihan.

4. Bagi Peneliti Selanjutnya

Hasil penelitian hendaknya dapat dijadikan sebagai gambaran bagi peneliti lain dan dapat dikembangkan lebih dalam mengingat adanya keterbatasan yang dimiliki oleh peneliti.

\section{DAFTAR RUJUKAN}

Adeltrudes B \& Marina O. 2010. Characterization and Evaluation of Antimicrobial Activity of the Essential Oil from the Leaves of Piper betle L. E-International Scientific Research Journal.2010; 2: 2-13.

Kementrian Kesehatan RI (2011). Formularium Obat Herbal Asli Indonesia, Jakarta

Kinanti, S. 2009. Rahasia Pintar Wanita. Aulya Publishing : Yogyakarta

Maytasari, GM. 2010. Perbedaan Efek Antifungi Minyak Atsiri Daun Sirih Hijau, Minyak Atsiri Daun Sirih Merah dan Resik-V Sabun Sirih Terhadap Pertumbuhan Candida Albicans Secara In Vitro. Skripsi Fakultas Kedokteran Universitas Surakarta

Wiknjosastro, H. 2007. Ilmu

Kandungan. Yayasan Bina Pustaka

Sarwono Prawirohardjo : Jakarta

Yuniarti, T. 2008. Tanaman Obat Tradisional. Medpress : Yogyakarta 